\title{
Heavy Metal Bioaccumulation in Enteromorpha intestinalis, (L.) Nees, a Macrophytic Algae: The Example of Kadin Creek (Western Anatolia)
}

\author{
Aykut Yozukmaz ${ }^{1}$, Murat Yabanli ${ }^{1 *}$, Fatma Sel ${ }^{1}$ \\ ${ }^{1}$ Mugla Sitki Kocman University - Fisheries Faculty, Department of Hydrobiology, Mugla, Menteşe, Turkey
}

\begin{abstract}
This study aims to specify the amount of ten heavy metals ( $\mathrm{Al}, \mathrm{Cr}, \mathrm{Mn}, \mathrm{Ni}, \mathrm{Cu}, \mathrm{Zn}, \mathrm{As}, \mathrm{Cd}, \mathrm{Hg}, \mathrm{Pb}$ ) in water, sediment and Enteromorpha intestinalis samples gathered from Kadin Creek in seasonal periods in 2011 and 2012 and to reveal bioaccumulation capability of this macrophytic algae. In this regard, heavy metal concentrations in the gathered samples were determined first with mineralization and then via inductively coupled plasma mass spectroscopy (ICP-MS) method. Findings suggested that algae could be used as an indicator in freshwater ecosystems in terms of studied heavy metals. With regard to bioconcentration factor values, in terms of water, algae accumulated aluminum the most and cadmium the least $(\mathrm{Al}>\mathrm{Cu}>\mathrm{As}>\mathrm{Zn}>\mathrm{Cr}>\mathrm{Mn}>\mathrm{Ni}>\mathrm{Pb}>\mathrm{Hg}>\mathrm{Cd}$ ), in terms of sediment, it accumulated mercury the most and aluminum the least $(\mathrm{Hg}>\mathrm{Cd}>\mathrm{As}>\mathrm{Zn}>\mathrm{Pb}>\mathrm{Mn}>\mathrm{Ni}$ $>\mathrm{Cr}>\mathrm{Cu}>\mathrm{Al}$ ). The highest rate of heavy metal concentration in algae was observed in summer when contaminants in water and dynamics of plant development increased. It was also observed that the mean mercury and cadmium concentrations exceeded the maximum residue limit values.
\end{abstract}

Key words: Heavy metals, Enteromorpha intestinalis, Kadın Creek.

*Author for correspondence: myabanli@gmail.com 


\section{INTRODUCTION}

In parallel with industrialization, urbanization and population growth, environmental problems like water pollution, which is a serious problem $^{1}$, have increased. Unlike organic materials, heavy metals, which are considered industrial contaminants, do not degrade. Thus, they accumulate in the water, earth, and deep sediment and in living organisms. Contamination of water with heavy metals is a serious concern in today's world ${ }^{2}$. In natural aquatic ecosystems, metals are normally at levels varying from nanogram to microgram per liter. Recently, heavy metals' exceeding the carrying capacity of waters has caused some problems with regard to aquatic ecosystem balance ${ }^{3}$.

Heavy metals can be accumulated by some organisms directly, such as macroalgae, or accumulated through the food chain, representing a serious risk for the whole ecosystem ${ }^{4}$. The uptake of heavy metals by macroalgae proceeds as follows: Chlorophyta $>$ Phaeophyta $>$ Rhodophyta .

Enteromorpha is the most common green macroalgae in the division Chlorophyta, order Ulvales and family Ulvaceae in estuaries and is of cosmopolitan distribution. Enteromorpha intestinelis is known as Gut Weed and Grass Kelp ${ }^{6,7}$. Despite being an edible algae species, it is not consumed in Turkey.

In recent years, many studies have been done on the existence of heavy metals by using green algae ${ }^{8,9,10}$. E. intestinelis was used for monitoring heavy metals $\mathrm{Cd}, \mathrm{Pb}, \mathrm{Ni}$, $\mathrm{Zn}$ and $\mathrm{Cu}$ in Weser Golden Horn ${ }^{6}$. Also, there have been studies on the biosorption of heavy metals using green algae as biosorbents. When biosorption studies are examined, it is seen that green algae effectively biosorb heavy metals ${ }^{11,12,13}$.

The purpose of this study is to determine the existence of 10 heavy metals $(\mathrm{Al}, \mathrm{Cr}$, $\mathrm{Mn}, \mathrm{Ni}, \mathrm{Cu}, \mathrm{Zn}, \mathrm{As}, \mathrm{Cd}, \mathrm{Hg}, \mathrm{Pb}$ ) in E. intestinalis plant populated in Kadın Creek habitat which is under the pressure of tourism and agricultural activities, to specify which heavy metal is biosorbed in the most effective way and to reveal if there is a risk in the consumption of this plant. As E. intestinalis is a submerged aquatic plant and continuously absorbs elements through its roots from sediment, heavy metal concentrations are also analyzed in this study.

\section{MATERIALS AND METHOD}

Kadın Creek is located in Akyaka, a town of Ula in the province of Mugla. According to information obtained via personal contact from Provincial Directorate of Agriculture, in this little town of which means of livelihood is agriculture and husbandry, 46790 tones agricultural products are obtained per year. This production consists of 10200 tons of fruit (4400 tons olives and 2000 tons oranges), 31340 tons of field plants (12250 tons oat, 10600 tons corns) and 5250 tons of vegetables (2100 tons watermelons, 1240 tons tomatoes). The most preferred agricultural fertilizers are ammonium nitrate, urea, triple super phosphate as well as organic fertilizers. For agricultural pest control, insecticides (aldicarp, dimethoate, 1,3- dichloropropane, lannate, malathion, diazinon) and fungicides (bravo, sulphur, copper sulphate and ridomid) are used. Also, there is a ready mixed concrete plant in the town.

There are two fisheries cooperatives in Akyaka using the harbor to which almost 95 large and small fishing boats (one of them is a seine boat, 2 are drifters and 1 is suitable for smack) are registered. Besides those fishing boats, there are also 25 large recreational crafts which organize daily expeditions for tourists in summer and 30 small touring boats which arrange hourly tours to the spring of Kadın Creek.

Kadın Creek is a meandering aquatic ecosystem of which depth is $6 \mathrm{~m}$ in some parts and whose length is $1700 \mathrm{~m}$ (Figure 1). Water discharge in the outlet of Kadin Creek is approximately $700 \mathrm{~L} \mathrm{~h}^{-1}$. It is fed by small streams during its journey towards the 
$\mathrm{sea}^{14}$. In the northern coast of the river, settlements are present. However, its southern coast is covered with reeds and there are dense algae colonies in some places. In addition to illegal waste disposal, excursion boats and fishing boats are significant causes of water pollution in this area ${ }^{15}$. Also, boat repair and dyeing work were being carried out around the studied creek.

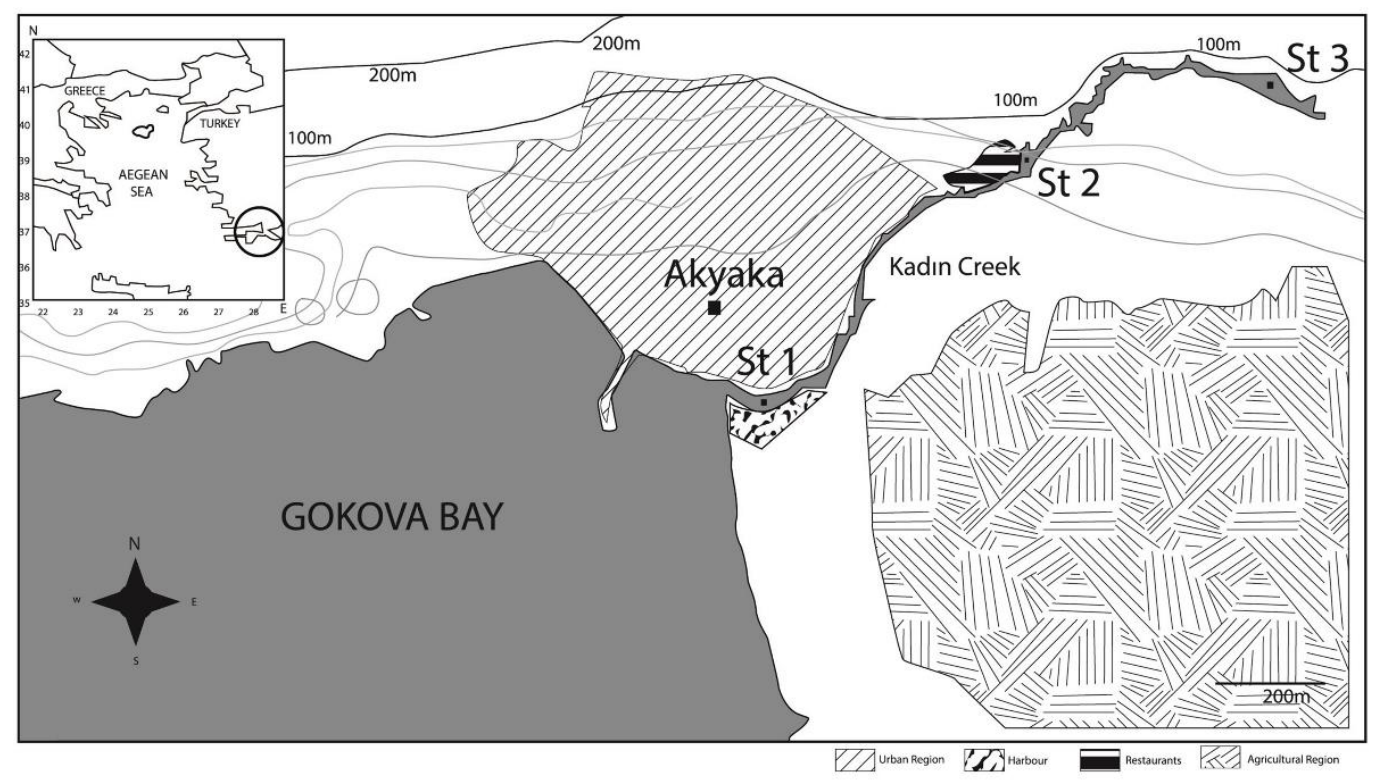

Figure 1- Study area

Water quality parameters [Temperature, $\mathrm{pH}$, Total Dissolved Solids (TDS), Dissolved Oxygen (DO) and Conductivity] in the study area were determined using an YSI 556 brand multiparameter.

Water samples were taken from $10-15 \mathrm{~cm}$ under the surface water with $10 \mathrm{~L}$ Hydrobios $^{\circledR}$ Plastic Water Sampler (PWS) between 2011 spring-2012 winter in seasonal periods into previously-washed 1 L-plastic containers and carried to laboratory in a freezer. The samples were filtered through a membrane filter with a pore size of $0.45 \mu \mathrm{m}$ and acidified with $0.1 \mathrm{~N} \mathrm{HNO}_{3}$ (65\% Suprapur Merck) to $\mathrm{pH}<2.0$. These samples were stored in a refrigerator at about $+4^{\circ} \mathrm{C}$ prior to analysis ${ }^{16}$. For the metals' analyses, the samples were taken into $10 \mathrm{~mL}$ plastic acid-fast test tubes and asseyed using ICP-MS (Agilent 7700x).

Sediment samples were taken with using Hydrobios ${ }^{\circledR}$ Van veen sediment trap (grasping area $250 \mathrm{~cm}^{2}$ ) at the same time period. Samples were carried to laboratory in proper conditions. Sediment samples were oven-dried at $60{ }^{\circ} \mathrm{C}$ to constant weight and fractions of $2 \mathrm{~mm}$ were obtained using nylon sieves. The $2 \mathrm{~mm}$ fraction was then ground in a mill (Fritsch Pulverisette, Germany) and sieved to ensure a maximum particle size of $100 \mu \mathrm{m}$. Finally, samples were preserved in the refrigerator at $4{ }^{\circ} \mathrm{C}$ until analysis. The element concentrations measured were based on dry weight after correcting for moisture content determined from separate subsamples dried in an oven for $48 \mathrm{~h}$ at $60{ }^{\circ} \mathrm{C}$. Digestates that could not be immediately analysed were stored at 4 ${ }^{\circ} \mathrm{C}$ until analysis. $1 \mathrm{~g}$ of sample was placed in $250 \mathrm{ml}$ Pyrex digestion tubes and a predigestion step was run at room temperature for $16 \mathrm{~h}$ with $15 \mathrm{ml}$ of $70 \% \mathrm{HNO}_{3}$. Then, the suspension was digested in a reflux condenser at $140{ }^{\circ} \mathrm{C}$ for $2 \mathrm{~h}$ and $30 \mathrm{~min}$. The obtained suspension was filtered through an ashless Whatman ${ }^{\circledR} 41$ filter, diluted to 50 $\mathrm{ml}$ with doubly de-ionised water and stored in polyethylene bottles at $4{ }^{\circ} \mathrm{C}$ for analyses ${ }^{17}$.

The concentrations of suspended particulate matter (SPM) in the water samples were measured by filtering water samples $(\sim 1.000 \mathrm{~mL})$ through pre-weighed $0.45 \mu \mathrm{m}$ paper 
filters. The filters were dried at $105^{\circ} \mathrm{C}$ for $12 \mathrm{~h}$ and weighed; the weight difference was used to calculate the amount of suspended particulate matter in the samples ${ }^{18}$.

The samples of E. intestinalis were collected between 2011 and 2012 seasonally with random sampling from the Kadın Creek. The sampling was taken from three different stations where the plants densely existed. The study area is shown in Fig. 1. The algae, which were botanized, were put into polyethylene bags and taken to the laboratory. The lengths of the macrophytic algae were between 18 and $114 \mathrm{~cm}$.

The samples of Grass Kelp which were brought to the laboratory were washed twice with distilled water (Human Power I Scholar UV trade marker water purification system) to clear them of periphyton and detritus. The algae samples were dried at $103^{\circ} \mathrm{C}$ for $24 \mathrm{~h}$ and the ash contents were determined by heating at $480^{\circ} \mathrm{C}$ for $4 \mathrm{~h} . \mathrm{HCl}$ (2.0 mL, suprapur, $30 \%$, Merck $\left.{ }^{\circledR}\right), \mathrm{HNO}_{3}\left(2.0 \mathrm{~mL}\right.$, suprapur, $65 \%$, Merck) and $\mathrm{H}_{2} \mathrm{O}_{2}$ (2.0 mL, suprapur, $30 \%$, Merck ${ }^{\circledR}$ ) were added to $1.0 \mathrm{~g}$ ash and the mixture was heated at $95^{\circ} \mathrm{C}$ on a hot plate for an hour. Afterwards, the overall volume was increased to 50 $\mathrm{mL}$ with ultra pure water ${ }^{19}$. Heavy metal concentrations in the solubilized algae were determined by inductively coupled plasma mass spectroscopy (ICP-MS, Agilent 7700x). Operating conditions of this device are given in Table 1.

Table 1- Operating condition of Agilent 7700X ICP-MS.

\begin{tabular}{ll}
\hline Instrument & Agilent 7700x ICP-MS \\
\hline RF power & $1550 \mathrm{~W}$ \\
RF matching & $2.1 \mathrm{~V}$ \\
Sample depth & $8 \mathrm{~mm}$ \\
Sample uptake rate & $0.1 \mathrm{~mL} \mathrm{~min}^{-1}$ \\
Plasma gas flow rate & $15 \mathrm{~L} \mathrm{~min}^{-1}$ \\
Auxiliary gas flow rate & $1.0 \mathrm{~L} \mathrm{~min}-1$ \\
Carrier gas flow rate & $0.95 \mathrm{~L} \mathrm{~min}^{-1}$ \\
Make-up gas flow rate & $0.0 \mathrm{~L} \mathrm{~min}{ }^{-1}$ \\
He gas flow & $4.3 \mathrm{~mL} \mathrm{~min}^{-1}$ \\
CeO $/$ Ce & $0.902 \%$ \\
Ratio $(2+)$ 70/140 & $0.944 \%$ \\
Spray chamber temp. & $2{ }^{\circ} \mathrm{C}$ \\
Spray chamber & Scott double-pass type \\
Torch & Quartz glass torch \\
Nebulizer type & MicroMist \\
Detector mode & Dual (pulse and analog counting) \\
Reaction cell gas & Helium was used as specific \\
& measured condition for all measured \\
& isotopes $\left({ }^{27} \mathrm{Al},{ }^{52} \mathrm{Cr},{ }^{55} \mathrm{Mn},{ }^{60} \mathrm{Ni},{ }^{63} \mathrm{Cu}\right.$, \\
& ${ }^{6}$ Zn, $\left.{ }^{75} \mathrm{As},{ }^{111} \mathrm{Cd},{ }^{200} \mathrm{Hg},{ }^{207} \mathrm{~Pb}\right)$. \\
\hline
\end{tabular}

Before the measurement, calibration of ICP-MS spectrometer using multielemental mixture of metal standards, $10 \mathrm{mg} \mathrm{L}^{-1}$ mix element standard stock solution (AccuTrace MES-21-1) and $10 \mathrm{mg} \mathrm{L}^{-1}$ mercury standard stock solution (AccuTrace MES-21-HG1, was carried out. Five multielement calibration solutions were prepared at different concentration levels (concentrations of $0-0.5-1-5-10 \mu \mathrm{g} \mathrm{L}^{-1}$ for $\mathrm{Hg}$ and concentrations of $0-5-10-50-100 \mu \mathrm{g} \mathrm{L}^{-1}$ for rest of the studied heavy metals) using Merck ${ }^{\circledR}$ suprapur purity nitric acid $\left(\mathrm{HNO}_{3}\right)$ matched to the samples matrix. The calibration curve for all the elements revealed a good linearity over the whole range of concentrations, with determination coefficients higher than 0.999. A five sample blank replicate analysis was used to calculate the limit of quantitation (LOQ = standard deviation (SD) 10) and limit of detection (LOD = standard deviation (SD) 3). The blank consisted of deionized water with $2 \% \mathrm{HNO}_{3}$. The detection limits of the studied metals for Aluminum (Al), Chromium (Cr), Manganese (Mn), Nickel (Ni), Copper (Cu), Zinc 
$(\mathrm{Zn})$, Arsenic (As), Cadmium $(\mathrm{Cd})$, Mercury $(\mathrm{Hg})$ and Lead $(\mathrm{Pb})$ were 5.34, 0.65, $0.06,0.02,0.11,0.82,0.05,0.003,0.05,0.06$ respectively $\left(\mu \mathrm{g} \mathrm{L}^{-1}\right)$ (Table 2$)$.

Table 2- LOD of heavy metals in ICP-MS $\left(\mu \mathrm{g} \mathrm{L}^{-1}\right)$.

\begin{tabular}{ccccccccccc} 
& Al & Cr & Mn & Ni & Cu & Zn & As & Cd & Hg & Pb \\
\hline LOD & 5.34 & 0.65 & 0.06 & 0.02 & 0.11 & 0.82 & 0.05 & 0.003 & 0.05 & 0.06 \\
\hline
\end{tabular}

\section{Bioconcentration Factor}

Bioconcentration of any chemical by aquatic organisms is described in terms of a biconcentration factor ${ }^{20}$. The biconcentration factor (BCF) was calculated using the formula below ${ }^{21}$.

$\mathrm{BCF}=$ Concentration of element in plant / Concentration of element in environment (water or sediment)

\section{Validation of Method}

The standard additional method ${ }^{22}$ was applied to whole grass kelp samples to correct matrix effects. The instrument was calibrated with standard solutions prepared by commercial materials. Analytical blanks were run in the same way as the samples and determined using standard solutions prepared in the same acid matrix. All chemicals and standard solutions used in the study were obtained from Merck ${ }^{\circledR}$ and were of analytical grade. Blank kelp samples were spiked with $1000 \mu \mathrm{g} \mathrm{kg}^{-1}$ mix standards (AccuTrace MES-21-1 including Al, Cr, Mn, Ni, Cu, Zn, As, Cd and Pb) and $100 \mu \mathrm{g}$ $\mathrm{kg}^{-1}$ mercury standart (AccuTrace MES-21-HG-1). Then ten homogenized blanks and ten homogenized spiked samples were digested and analyzed using ICP-MS. The amount of spiked metal recovered after the digestion of the spiked samples was used to calculate percentage recovery. The validation results (differing between $92.50 \%$ $97.80 \%$ ) allow us to deduce a good reliability of digestion process and ICPMS analysis.

\section{Data Analysis}

Statistical data analyses were carried out using the SPSS software version 15.0. The relationship between the groups was determined using ANOVA followed by Tukey test. A level of 0.05 alpha was selected to assess the significance between groups. Then, the correlation between suspended solid matter in the water and the concentration of the heavy metals from algae samples was determined using Pearson correlation test. The significance was reported at $\mathrm{p}<0.05$ and $\mathrm{p}<0.01$.

\section{RESULTS AND DISCUSSION}

In this study, heavy metal concentrations in 20 microalgae samples and water samples gathered seasonally from Kadin Creek were determined. Table 3 shows the heavy metal concentrations detected in plant samples, mean heavy metal concentrations detected in water samples are presented in Table 4 and mean heavy metal concentrations detected in sediment samples are presented in Table 5 also. Physicochemical parameters (temperature, conductivity, TDS, suspended solids, saltiness, dissolved oxygen and $\mathrm{pH}$ ) measured in the water samples are shown in Table 6. Any significant differences among the groups were determined by ANOVA and Tukey test ( $>0.05$ ). 
Table 3- Heavy metal concentrations detected in E. intestinalis samples $\left(\mathrm{mg} \mathrm{kg}^{-1} \mathrm{dw}\right)$

\begin{tabular}{ccccccccccc}
\hline $\mathrm{n}=20$ & $\mathbf{A l}$ & $\mathbf{C r}$ & $\mathbf{M n}$ & $\mathbf{N i}$ & $\mathbf{C u}$ & $\mathbf{Z n}$ & $\mathbf{A s}$ & $\mathbf{C d}$ & $\mathbf{H g}$ & $\mathbf{P b}$ \\
\hline Min & 127.00 & 0.19 & 2.94 & 1.02 & 1.50 & 7.20 & 4.34 & 0.01 & 0.12 & 2.49 \\
Max & 766.42 & 22.71 & 39.23 & 16.81 & 38.95 & 68.22 & 29.36 & 0.19 & 1.09 & 8.02 \\
Mean & 352.48 & 6.88 & 18.52 & 8.59 & 15.13 & 31.95 & 12.00 & 0.10 & 0.51 & 4.91 \\
$\mathbf{\pm} \mathbf{s e}$ & 46.17 & 1.46 & 3.02 & 1.14 & 2.69 & 4.76 & 1.48 & 0.01 & 0.09 & 0.35 \\
\hline
\end{tabular}

Table 4- Mean heavy metal concentrations detected in water samples $\left(\mu \mathrm{g} \mathrm{L}^{-1}\right)$

\begin{tabular}{ccccccccccc}
\hline $\mathrm{n}=12$ & $\mathbf{A l}$ & $\mathbf{C r}$ & $\mathbf{M n}$ & $\mathbf{N i}$ & $\mathbf{C u}$ & $\mathbf{Z n}$ & $\mathbf{A s}$ & $\mathbf{C d}$ & $\mathbf{H g}$ & $\mathbf{P b}$ \\
\hline Min & 1.06 & 0.01 & 2.40 & 1.08 & 0.15 & 0.36 & 0.72 & 0.01 & 0.01 & 1.15 \\
Max & 8.56 & 2.38 & 8.02 & 8.56 & 0.91 & 11.02 & 1.10 & 1.34 & 1.93 & 3.32 \\
Mean & 4.47 & 1.19 & 5.48 & 3.44 & 0.49 & 4.57 & 0.87 & 0.38 & 0.52 & 2.25 \\
$\mathbf{\pm} \mathbf{s e}$ & 1.00 & 0.26 & 0.60 & 0.83 & 0.09 & 1.19 & 0.03 & 0.16 & 0.24 & 0.23 \\
\hline
\end{tabular}

Table 5- Mean heavy metal concentrations detected in sediment samples ( $\left.\mathrm{mg} \mathrm{kg}^{-1} \mathrm{dw}\right)$

\begin{tabular}{ccccccccccc} 
n=3 & $\mathbf{A l}$ & $\mathbf{C r}$ & $\mathbf{M n}$ & $\mathbf{N i}$ & $\mathbf{C u}$ & $\mathbf{Z n}$ & $\mathbf{A s}$ & $\mathbf{C d}$ & $\mathbf{H g}$ & $\mathbf{P b}$ \\
Min & 6128.82 & 53.92 & 230.73 & 142.47 & 30.13 & 99.35 & 10.05 & 0.36 & 0.01 & 61.42 \\
Max & 6624.51 & 62.75 & 227.56 & 184.62 & 53.30 & 104.44 & 12.71 & 0.71 & 0.03 & 72.11 \\
Mean & 6518.71 & 65.47 & 232.30 & 159.42 & 46.28 & 101.23 & 11.27 & 0.40 & 0.02 & 69.75 \\
$\mathbf{\pm}$ se & 202.36 & 3.60 & 1.29 & 17.21 & 9.46 & 2.08 & 1.09 & 0.14 & 0.01 & 4.36 \\
\hline
\end{tabular}

Table 6- Mean values of water quality parameters found at study site.

\begin{tabular}{ccccccc} 
& Winter & Spring & Summer & Autumn & Mean & $\mathbf{\pm}$ se \\
\hline Temperature $\left.\mathbf{~}^{\circ} \mathbf{C}\right)$ & 14.81 & 14.88 & 16.71 & 15.03 & 15.36 & 0.46 \\
Conductivity $\left(\boldsymbol{\mu S ~ ~ c m ^ { - 1 }}\right)$ & 5602 & 5200 & 5891 & 5714 & 5602 & 146.53 \\
TDS $\left(\mathbf{m g ~ L}^{-1}\right)$ & 382 & 338 & 412 & 396 & 382 & 15.89 \\
Suspended Solid Matter $\left(\mathbf{m g ~ L}^{-\mathbf{1}}\right)$ & 4.583 & 4.055 & 4.567 & 4.751 & 4.489 & 0.15 \\
Salinity $(\mathbf{p p m})$ & 3.22 & 2.86 & 3.37 & 3.28 & 3.18 & 0.11 \\
Dissolved Oxygen $\left(\mathbf{m g ~ L}^{-\mathbf{1}}\right)$ & 8.61 & 8.42 & 7.89 & 8.12 & 8.26 & 0.16 \\
$\mathbf{p H}$ & 7.03 & 8.10 & 7.24 & 7.12 & 7.37 & 0.25 \\
\hline
\end{tabular}

Looking at the results of the Tukey HSD Post Hoc test, when the distribution of heavy metals in algae was analyzed seasonally, it was found that there was a statistically significant difference between summer-fall and summer-winter seasonal periods in terms of all the elements $(p<0.05)$. There was no statistically significant difference among heavy metal concentrations in algae in the fall-winter period ( $p>0.05)$. The highest amount of heavy metal concentration in algae samples was found in summer. In terms of water According to BCF data, the uptake order of heavy metals in the algae was $\mathrm{Al}>\mathrm{Cu}>\mathrm{As}>\mathrm{Zn}>\mathrm{Cr}>\mathrm{Mn}>\mathrm{Ni}>\mathrm{Pb}>\mathrm{Hg}>\mathrm{Cd}$. The $\mathrm{BCF}$ values are shown in Figure 2. 


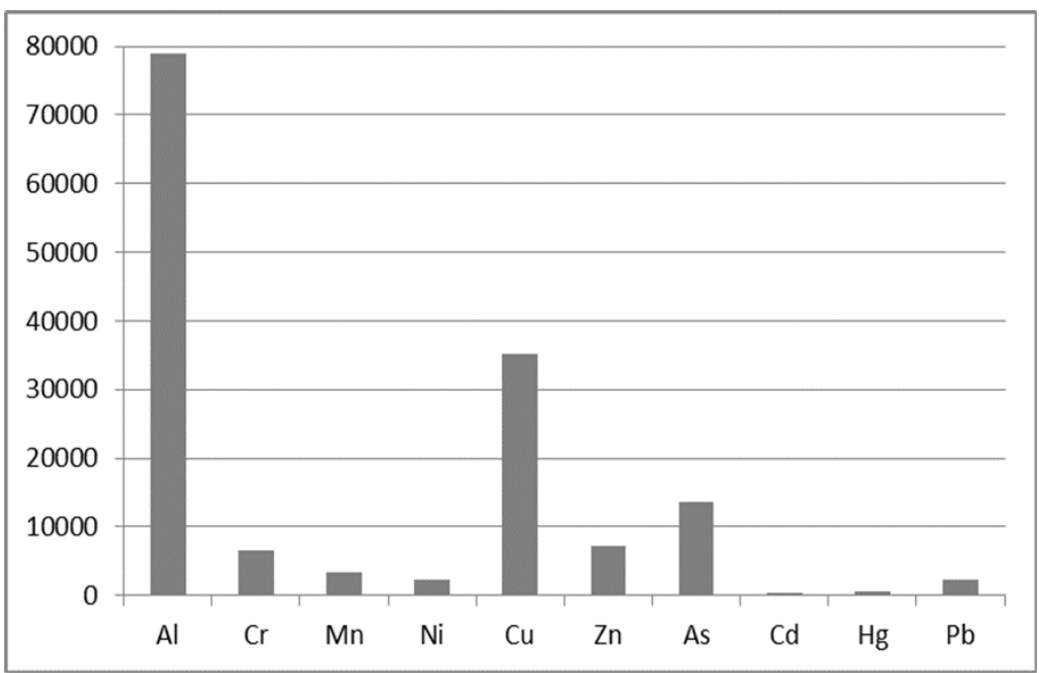

Figure 2- BCF rates in the algae in terms of water.

According to $\mathrm{BCF}$ results calculated in terms of heavy metal concentrations obtained from sediment, heavy metals were biosorbed in the plant as $\mathrm{Hg}>\mathrm{Cd}>\mathrm{As}>\mathrm{Zn}>\mathrm{Pb}>\mathrm{Mn}>\mathrm{Ni}>$ $\mathrm{Cr}>\mathrm{Cu}>\mathrm{Al}$. Plants take toxic heavy metals as well as micro-macro and functional nutrients into their tissues through their roots from sediment in order to carry out their biological functions. While $\mathrm{Zn}, \mathrm{Mn}$ and $\mathrm{Cu}$ are micro nutrients for plants, $\mathrm{Ni}$ and $\mathrm{Al}$ are regarded as functional nutrients ${ }^{23}$. Therefore, according to BCF results based on sediment in this study, specifically toxic heavy metals displayed accumulation in the plant (Figure 3).

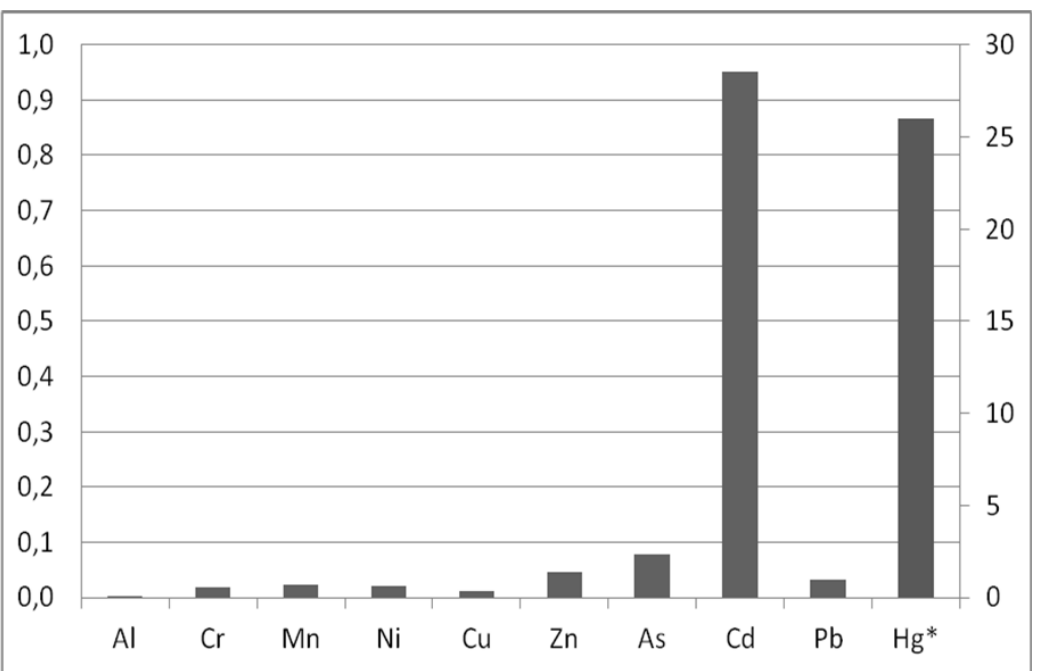

Figure 3- BCF rates in the algae in terms of sediment.

(*Hg is shown in secondary axis)

Suspended solid matter consists of various organic and inorganic matters. Most of them attach to the surfaces of particles in water. Organic matters in the water have the ability to bind to the heavy metals ${ }^{24,25}$. In this study, as shown in Figure 4 , when suspended solid matter increased, the amount of total heavy metals concentration in $E$. intestinalis decreased (summer-autumn period); the reverse also being seen with a decrease in solid matter and an increase in heavy metal presence (winter-spring period). Considering the relationship between the concentration of each heavy metal and suspended solid matter in the water obtained from algae samples, a strong negative correlation was determined. Specifically correlation test results showed $\mathrm{r}$ values of $-0.727,-0.477,-0.515,-0.503,-0.607,-0.727,-0.624,0.386^{*}$ ( $\left.p<0.05\right), 0.008$, and $-0.706(\mathrm{p}<0.01)$ for $\mathrm{Al}, \mathrm{Cr}, \mathrm{Mn}, \mathrm{Ni}, \mathrm{Cu}, \mathrm{Zn}, \mathrm{As}, \mathrm{Cd}, \mathrm{Hg}$, and $\mathrm{Pb}$ respectively. 


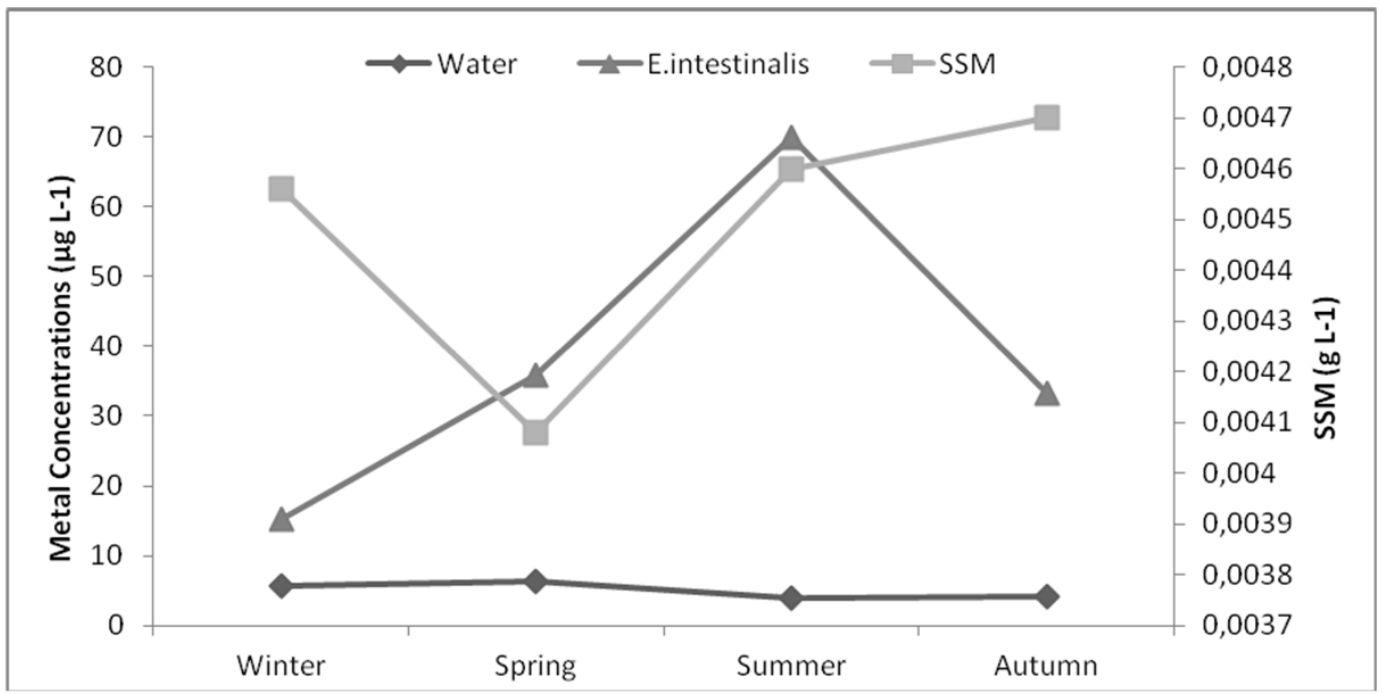

Figure 4- Changes in total mean heavy metal concentrations in water and algae with regard to suspended solid matter (SSM), seasonally.

The determined heavy metal concentrations in plant samples were directly proportionate to heavy metal contaminant load in the study area; they at times differ with relation to studied species and season.

The mean concentrations of heavy metals are observed mostly in spring due to an increase in agricultural activities (fertilization, disinfestation), maintenance and repair of boats for summer season (painting and cleaning) and input of contaminants as a result of precipitation.

The research showed that the highest rate of heavy metal concentrations in plant samples was obtained in summer. As summer is the holiday season in this region, in parallel to population growth in the region during that season, restaurants and hotels started to actively operate and recreational activities increased.

Considering seasonal effects of spring activities, contaminants in water increased. Seasonal changes in heavy metal concentrations in algae are related to growth dynamics and changes in metal concentrations within the environment ${ }^{26}$. As the rates of photosynthesis and respiration in plants increased in summer, metal assimilation accelerated ${ }^{27}$. The highest rate of heavy metal concentrations in E. intestinalis samples gathered from the Black Sea coast of Bulgaria was found in spring and summer ${ }^{28}$.

Heavy metal concentrations detected in macroalgae varied by geochemical structure within the environment and anthropogenic input status.

When the results of this study are compared to recent studies on Enteromorpha intestinalis, the concentrations in this study are found higher than others in terms of copper accumulation (Table 7).

In terms of Enteromorpha spp. in uncontaminated areas, copper concentration was between 6-12 $\mathrm{mg} \mathrm{kg}^{-1} \mathrm{dw}$; and in contaminated areas it was between $20-70 \mathrm{mg} \mathrm{kg}^{-1}$ $\mathrm{dw}^{37}$. The mean copper concentration obtained in this study was $15.13 \mathrm{mg} \mathrm{kg}^{-1} \mathrm{dw}$, a close value to upper limit obtained in uncontaminated areas. However, in a study done in the aquatic ecosystem near which copper mining was dense, copper concentration was found to be very high $\left(148 \mathrm{mg} \mathrm{kg}^{-1} \mathrm{dw}\right)^{28}$. Similarly, in a different study, the effect of copper mining was observed in the species E. compressa $\left(310-750 \mathrm{mg} \mathrm{kg}^{-1}\right.$ $\mathrm{dw})^{38}$. Also, during literature review, it is observed that there are only a few studies related to arsenic and aluminium. In order to fill this gap in the literature, more bioaccumulation studies (especially on arsenic) on this aquatic plant should be done by researchers. 
Table 7- Comparision of studied heavy metal concentrations in E. intestinalis and Enteromorpha sp. with other studies (mg kg-1).

\begin{tabular}{|c|c|c|c|c|c|c|c|c|c|c|c|}
\hline Area & Algea & Al & $\mathrm{Cr}$ & Mn & $\mathbf{N i}$ & $\mathbf{C u}$ & $\mathbf{Z n}$ & As & Cd & Hg & $\mathbf{P b}$ \\
\hline $\begin{array}{c}\text { Mazatlán Harbour, } \\
\text { Mexico }^{29}\end{array}$ & $\begin{array}{l}\text { Enteromorpha } \\
\text { intestinalis }\end{array}$ & - & 3.8 & 114 & 11.7 & 8.9 & 99.8 & - & 0.3 & - & - \\
\hline El-Mex, Egypt ${ }^{30}$ & $\begin{array}{l}\text { Enteromorpha } \\
\text { intestinalis }\end{array}$ & - & - & 54.6 & 11.8 & 9.7 & 38.4 & - & 2.1 & 0.1 & 21.3 \\
\hline $\begin{array}{c}\text { Istanbul Strait, } \\
\text { Turkey }^{31}\end{array}$ & $\begin{array}{l}\text { Enteromorpha } \\
\text { intestinalis }\end{array}$ & - & $5.2 \pm 2.6$ & - & - & $8.40 \pm 0.11$ & $12.9 \pm 6.2$ & $4.6 \pm 3.0$ & $1.08 \pm 0.02$ & - & $5.3 \pm 2.8$ \\
\hline $\begin{array}{l}\text { Skjerstadfjorden, } \\
\text { Nordland county }{ }^{32}\end{array}$ & $\begin{array}{l}\text { Enteromorpha } \\
\text { intestinalis }\end{array}$ & - & - & 130 & - & 4.9 & 25 & 4.9 & 0.12 & 0.014 & - \\
\hline Narlidere, Turkey ${ }^{33}$ & Enteromorpha sp. & - & $\begin{array}{c}4.98 \pm \\
0.37\end{array}$ & - & - & $6.64 \pm 0.98$ & $86.3 \pm 4.63$ & - & $\begin{array}{l}21.0 \pm \\
7.25\end{array}$ & $\begin{array}{c}336.3 \pm \\
130.9\end{array}$ & $\begin{array}{c}4.76 \pm \\
0.66\end{array}$ \\
\hline Urla, Turkey ${ }^{33}$ & Enteromorpha sp. & - & $\begin{array}{l}3.15 \pm \\
0.02\end{array}$ & - & - & $4.43 \pm 0.06$ & $97.5 \pm 0.82$ & - & $\begin{array}{c}42.7 \pm \\
0.68\end{array}$ & $\begin{array}{c}67.9 \pm \\
1.93\end{array}$ & $\begin{array}{c}1.04 \pm \\
0.07\end{array}$ \\
\hline Foça, Turkey ${ }^{33}$ & Enteromorpha sp. & - & $\begin{array}{l}4.45 \pm \\
1.72\end{array}$ & - & - & $10.7 \pm 0.96$ & $74.8 \pm 15.3$ & - & $\begin{array}{c}12.6 \pm \\
3.46\end{array}$ & $\begin{array}{c}90.4 \pm \\
14.9\end{array}$ & $\begin{array}{l}9.98 \pm \\
2.92\end{array}$ \\
\hline Dardanos, Turkey ${ }^{33}$ & Enteromorpha sp. & - & $\begin{array}{l}9.63 \pm \\
1.86\end{array}$ & - & - & $8.89 \pm 0.03$ & $68.8 \pm 2.26$ & - & $\begin{array}{c}44.1 \pm \\
7.99\end{array}$ & $\begin{array}{l}89.4 \pm \\
2.01\end{array}$ & $\begin{array}{c}2.95 \pm \\
0.28\end{array}$ \\
\hline $\begin{array}{l}\text { Abu-Qir Bay, } \\
\text { Egypt }^{34}\end{array}$ & Enteromorpha sp. & - & - & 76.84 & 11.73 & 4.60 & 31.1 & - & 3.16 & $167.63^{*}$ & 17.76 \\
\hline $\begin{array}{c}\text { Abu Qir Bay, } \\
\text { Egypt }^{35}\end{array}$ & Enteromorpha sp. & - & - & 44.08 & - & 6.54 & 38.12 & - & 1.03 & - & 9.91 \\
\hline $\begin{array}{c}\text { The Gulf of Kutch, } \\
\text { India }^{36}\end{array}$ & Enteromorpha sp. & - & $1.78 \pm 0.3$ & $5.6 \pm 2.3$ & $1.2 \pm 0.2$ & $9.8 \pm 2.1$ & $66.4 \pm 2.2$ & - & $1.26 \pm 0.1$ & - & $0.6 \pm 0.1$ \\
\hline $\begin{array}{l}\text { The Gulf of Kutch, } \\
\text { India }^{36}\end{array}$ & Enteromorpha $s p$. & - & $1.18 \pm 0.2$ & $7.3 \pm 2.2$ & $1.1 \pm 0.1$ & $7.6 \pm 1.4$ & $97 \pm 26$ & - & $0.88 \pm 0.1$ & - & $0.2 \pm 0.1$ \\
\hline $\begin{array}{c}\text { Akyaka, Turkey (In } \\
\text { This Study) }\end{array}$ & $\begin{array}{c}\text { Enteromorpha } \\
\text { intestinalis }\end{array}$ & $352.48 \pm 46.17$ & $6.88 \pm 1.46$ & $18.52 \pm 3.02$ & $8.59 \pm 1.14$ & $15.13 \pm 2.69$ & $31.95 \pm 4.76$ & $12.00 \pm 1.48$ & $0.10 \pm 0.01$ & $0.51 \pm 0.09$ & $4.91 \pm 0.35$ \\
\hline
\end{tabular}


According to $\mathrm{BCF}$ data, the uptake order of heavy metals in the algae was $\mathrm{Al}>\mathrm{Cu}>$ $\mathrm{As}>\mathrm{Zn}>\mathrm{Cr}>\mathrm{Mn}>\mathrm{Ni}>\mathrm{Pb}>\mathrm{Hg}>\mathrm{Cd}$. An accumulation model of $\mathrm{Cu}>\mathrm{Pb}>\mathrm{Cd}$ for E.intestinalis was found in another research supports the results of this study ${ }^{28}$. When the mean heavy metal concentrations obtained from E.intestinalis, an edible species, were compared to French edible seaweed limits $\left(\mathrm{Pb}:<5 \mathrm{mg} \mathrm{kg}^{-1} \mathrm{dw}, \mathrm{Cd}:<0.5\right.$ $\mathrm{mg} \mathrm{kg}{ }^{-1} \mathrm{dw}, \mathrm{Hg}$ : $\left.<0.1 \mathrm{mg} \mathrm{kg}^{-1} \mathrm{dw}\right)^{39}$, the amount of mercury measured was higher $\left(0.51 \mathrm{mg} \mathrm{kg}^{-1} \mathrm{dw}\right)$. However, since the species of E. intestinalis was a heavy metal indicator, this result was expected.

\section{CONCLUSION}

As a result of the obtained findings, it was affirmed that algae was a significant indicator in freshwater in terms of heavy metal contamination. In terms of water, bioconcentration factor values $(\mathrm{Al}>\mathrm{Cu}>\mathrm{As}>\mathrm{Zn}>\mathrm{Cr}>\mathrm{Mn}>\mathrm{Ni}>\mathrm{Pb}>\mathrm{Hg}>\mathrm{Cd}$ ) were examined, algae accumulated aluminum the most and accumulated cadmium the least. In terms of sediment, algae accumulated mercury the most and aluminum the least according to data on bioconcentration factor $(\mathrm{Hg}>\mathrm{Cd}>\mathrm{As}>\mathrm{Zn}>\mathrm{Pb}>\mathrm{Mn}>$ $\mathrm{Ni}>\mathrm{Cr}>\mathrm{Cu}>\mathrm{Al}$ ). The highest rate of heavy metal concentration in algae was observed in summer when contaminants in water and dynamics of plant development increased. The mean mercury and concentration exceeded the EC 629/2008 maximum residue limits ${ }^{40}$. The main sources for heavy metals within the region are tourism, boating and agricultural activities. So as to take heavy metal contamination under control, organic fertilizers should be used more than inorganic (chemical based) fertilizers and biological pest control should be preferred over chemical pest control. Hazardous wastes created by maintenance and repair activities of boats should be gathered before reaching aquatic ecosystem by the application of some special methods and should be sent to particular facilities in which they can be eliminated. Also, it may be suggested that educational activities are carried out in order to raise the awareness of local people towards environmental pollution.

\section{ACKNOWLEDGEMENTS}

The authors would like to thank Assistant Prof. Daniella Giannetto and Research Assistant Nisan Yozukmaz (Mugla Sitki Kocman University) for their contribution to the editing of the manuscript.

\section{REFERENCES}

1. Satya N, Ojha CSP, Mishra SK, Chaube UC, Sharma PK. Cadmium and chromium removal by aquatic plant. Int J Environ Sci. 2011; 1: 1297-1304.

2. Miretzky P, Saralegui A, Cirelli AF. Aquatic macrophytes potential for the simultaneous removal of heavy metals (Buenos Aires, Argentina). Chemosphere. 2004; 57: 997-1005.

3. Ndimele PE, Jimoh AA. Water hyacinth (Eichhornia crassipes (Mart.) Solms.) in phytoremediation of heavy metal polluted water of Ologe Lagoon, Lagos, Nigeria. Res $J$ Environ Sci. 2011; 5: 424-433.

4. Vecchia FD, Marzocchi M, Maistro S, Moro I. Morpho-physiological effects of cadmium on two Ulva species. Algol Stud. 2012; 138: 13-26.

5. Al-Shwafi NA, Rushdi AI. Heavy metal concentrations in marine green, brown, and red seaweeds from coastal waters of Yemen, the Gulf of Aden. Environ Geol. 2008; 55(3): 653-660.

6. Müller M, Schirmer M, Kettler J. Use of Enteromorpha intestinalis (Chlorophyceae) for active biomonitoring of heavy metals in the Weser estuary. Neth J Aquat Ecol. 1993; 27: 189-195. 
7. Ruangchuay R, Dahamat S, Chirapat A, Notoya M. Effects of culture conditions on the growth and reproduction of Gut Weed, Ulva intestinalis Linnaeus (Ulvales, Chlorophyta). Songklanakarin Journal of Science and Technology. 2012; 34(5): 501-507.

8. Topcuoglu S, Guven KC, Balkis N, Kirbasoglu C. Heavy metal monitoring of marine algae from the Turkish Coast of the Black Sea, 1998-2000. Chemosphere. 2003; 52: 16831688.

9. Zbikowski R, Szefer P, Latala A. Comparison of green algae Clodophora sp. and Enteromorpha sp. as potential biomonitors of chemical elements in the southern Baltic. Sci Total Environ. 2007; 387: 320-332.

10. Strezov A, Nonova T. Influence of Macroalgal diversity on accumulation of radionuclides and heavy metals in Bulgarian Black Sea ecosystems. J Environ Radio. 2009; 100: 144150 .

11. Hashim MA, Chu KH. Biosorption of cadmium by brown, green and red seaweeds. Chem Eng J. 2004; 97: 249-255.

12. Yalçın E, Çavuşoğlu K, Maraş M, Bıyıkoğlu M. Biosorption of lead (II) and copper (II) metal ions on Cladophora glomerata (L.) Kütz. (Chlorophyta) algae: Effect of algal surface modification. Acta Chim Slov. 2008; 55: 228-232.

13. Lee YC, Chang SP. The biosorption of heavy metals from aqueous solution by Spirogyra and Cladophora filamentous macroalgae. Bioresource Technology. 2011; 102(9): 52975304.

14. Yusufoğlu A. A critical review of the tools and techniques used in coastal planning: Case study Mugla-Gokova special environmental protection area [Ms thesis]. Ankara, Turkey: The Graduate School of Natural and Applied Sciences of Middle East Technical University; 2010.

15. Demirak A, Y1lmaz HA, Keskin F, Şahin Y, Akpolat O. Investigation of heavy metal content in the suspended particulate matter and sediments of inner Gokova Bay and creeks. Environ Monit Assess. 2011; 184: 7113-7124.

16. Garcia-Hernandez J, Glenn EP, Artiola J, Baumgartner DJ. Bioaccumulation of Selenium (Se) in the Cienega de Santa Clara Wetland, Sonora, Mexico. Ecotox Environ Safe. 2000; 46: 298-304.

17. Sastre J, Sahuquillo A, Vidal M, Rauret G. Determination of $\mathrm{Cd}, \mathrm{Cu}, \mathrm{Pb}$ and $\mathrm{Zn}$ in environmental samples: microwave-assisted total digestion versus aqua regia and nitric acid extraction. Analytica Chimica Acta. 2002; 462: 59-72.

18. Onderka M, Pekárová P. Retrieval of suspended particulate matter concentrations in the Danube River from Landsat ETM data. Sci Total Environ. 2008; 397: 238-243.

19. Sasmaz A, Obek E. The accumulation of arsenic, uranium, and boron in Lemna gibba L. exposed to secondary effluents. Ecol Eng. 2009; 35: 1564-1567.

20. Phetsombat S, Kruatrachue M, Pokethitiyook P, Upatham S. Toxicity and bioaccumulation of cadmium and lead in Salvinia cucullata. J Environ Biol. 2006; 27: 645-652.

21. Sadiq M. Forest fire ash impact on micro- and macroalgae in the receiving waters of the east coast of South Korea. Mar Pollut Bullet. 1992; 45: 203-209.

22. Dural M, Göksu MZL, Özak AA. Investigation of heavy metal levels in economically important fish species captured from the Tuzla lagoon. Food chemistry. 2007; 102: 415421.

23. Bergmann W. Colour atlas: nutritional disorders of plants. Stuttgart:1992; p.1-741.

24. Balkis N, Aksu A, Okuş E, Apak R. Heavy metal concentration in water, suspended matter, and sediment from Gökova Bay, Turkey. Envıron Monit Assess. 2010; 167: 359370.

25. Sklodowski P, Maciejewska A, Kwiatkowska J. The effect of organic matter from brown coal on bioavailability of heavy metals in contaminated soils. In: Twardowska I, Allen HE, Häggblom MM, Stefaniak S, editors. Soil and water pollution monitoring, protection and remediation. Netherland: Springer; 2006. p. 299-307.

26. Haritonidis S, Malea P. Seasonal and local variation of $\mathrm{Cr}, \mathrm{Ni}$ and Co concentrations in Ulva rigida C. Agardh and Enteromorpha linza (Linnaeus) from Thermaikos Gulf, Greece. Environ Pollut. 1995; 89(3): 319-327.

27. Villares R, Puente X, Carballeira A. Seasonal variation and backround levels of heavy metals in two green seaweeds. Environ Pollut. 2002; 119: 79-90. 
28. Strezov A, Nonova T. Environmental monitoring of heavy metals in Bulgarian Black Sea green algae. Environ Monit and Assess. 2005; 105: 99-110.

29. Páez-Osuna F, Ochoa-Izaguirre MJ, Bojórquez-Leyva H, Michel-Reynoso IL. Macroalgae as biomonitors of heavy metal availability in coastal lgoons from subtropical pacific of Mexico. B Environl Contam Tox. 2000; 64: 846-851.

30. Mohamed LA, Khaled A. Comparative study of heavy metal distribution in some coastal seaweeds of Alexandria, Eygpt. Chem Ecol. 2005; 21(3): 181-189.

31. Kut D, Topcuoğlu S, Esen N, Küçükcezzar R, Güven KC. Trace metals in marine algae and sediment samples from the Bosphorus. Water Air and Soil Poll. 2000; 118: 27-33.

32. Mæhre HK, Malde MK, Eilertsen KE, Elvevoll EO. Characterization of protein, lipid and mineral contents in common Norwegian seaweeds and evaluation of their potential as food and feed. J. Sci. Food Agr. 2014; 94(15), 3281-3290.

33. Akcali I, Kucuksezgin F. A biomonitoring study: heavy metals in macroalgae from eastern Aegean coastal areas. Marine Poll Bull. 2011; 62(3), 637-645.

34. El-Din NS, Mohamedein LI, El-Moselhy KM. Seaweeds as bioindicators of heavy metals off a hot spot area on the Egyptian Mediterranean Coast during 2008-2010. Environ Monit Assess. 2014; 186(9), 5865-5881.

35. Abdallah MAM. (2010). Heavy metal monitoring in marine seaweeds from the southeastern Mediterranean Sea off the Egyptian coast, 2006-2009. United Nations Environment Programme Mediterranean Action Plan, Regional Activity Centre for Specially Protected Areas. Proceedings of the 4th Mediterranean Symposium on marine vegetation, Yasmine Hammamet, 2-4 December 2010, 11-16.

36. Chakraborty S, Bhattacharya T, Singh G, Maity JP. Benthic macroalgae as biological indicators of heavy metal pollution in the marine environments: A biomonitoring approach for pollution assessment. Ecotoxicol Environ Saf. 2014; 100: 61-68.

37. Brown MT, Hodgkinson W N, Hurd CL. Spatial and temporal variations in the copper and zinc concentrations of two green seaweeds from Otago Harbour, New Zealand. Mar Environ Res. 1999; 47: 175-184.

38. Ratkevicius N, Correa JA, Moenne A. Copper accumulation, synyhesis of ascorbate and activation of ascorbate peroxidase in Enteromorpha compressa (L.) Grev. (Chlorophyta) from heavy metal-enriched environments in northern Chile. Plant Cell Environ. 2003; 26: 1599-1608.

39. Besada V, Andrade JM, Schultze F, González JJ. Heavy metals in edible seaweeds commercialised for human consumption. Journal of Marine Systems. 2009; 75: 305-313.

40. EU COMMISSION. Commission Regulation (EC) No. 629/2008 of 2 July 2008 amending Regulation (EC) No. 1881/2006 setting maximum levels for certain contaminants in foodstuffs. Official Journal of the European Union L, 2008; 173: 6-9.

Received: February 08, 2016

Accepted: October 13, 2016 